\title{
Psychiatry Remembered
}

M. VAlentine, 204 Redland Road, Bristol

In 1947 Britain had its severest winter since 1881, starving sheep came off the hills looking for sustenance in the towns, and the snow went on until April. That was when I boarded the $M V$ Batory, later renowned or infamous for its espionage traffic, to be decanted into an early heat wave in New York. Times Square was hot and hectic, the steaks were two inches thick instead of two ounces a week, so my wife and I pushed on to our destination in Hartford, Connecticut where I had been appointed psychiatrist after an impressive series of transatlantic cablegrams. Hartford was a dignified and prosperous town, 'the insurance city of the world.' The Hartford Retreat had been founded in 1822, one of the earliest American hospitals to be devoted to mental illness; it had undergone a radical change in the 1930s under the entrepreneurial genius of Dr Charles C. Burlingame and was re-named the Institute of Living.

Its resplendent campus was decorated with venerable trees, flowering shrubs and a scattering of attractive villas, variously styled after American Colonial or mock Tudor models. After the grey deprivations of post-war Britain, its lushness, despite its non-profit status, gave rise to images of Citizen Kane or even musical comedy. Could one take seriously its fleet of 22 cars with uniformed girl drivers taking the 'guests' out on their 'Pick-a-Trip' tours at $\$ 3.50$ an hour? Or its indoor and outdoor pools, its squash court and gymnasium, outdoor theatre, his and hers hairdressing saloons ('Clipper Deck' and 'Chez Nous'), Ye Glaziery and Ye Silver Smithy? Nonetheless, under the tinsel there was a lot of good stuff. The Department of Educational Therapy was years ahead of its time, even if one wondered whether sick people could concentrate on extension courses; and the Research Building sheltered and encouraged original work in neurophysiology and psychology in addition to housing a fine library.

We had medical staff meetings with heads of departments each morning at 8 a.m. Woe to any junior who had failed to keep the relatives happy; the case was stripped from him and awarded to another. We were required to be in our offices between 12 and 1 to take incoming calls and dictate letters and notes. Relatives, saddled with the combined worries of family illness and the high costs of hospitalisation, developed high anxiety levels and looked for evident results.

Even at that time, medical institutions were very conscious of potential litigation, and malpractice claim avoidance ranked paramount in their priorities. The wishes of referring physicians took precedence in deciding treatment; medical notes were anonymously typed without signature or initials, and before being committed to typescript were vetted by an administrative assistant lest anything actionable had inadvertently crept in. By contrast, it was surprising that people could be committed to detention merely on the documentation and without examination. In addition to the individual interviews, all patients of each medical team had to be seen twice a day in rounds of the campus, and also in the course of a night round by a duty officer.

Dr Burlingame was the dynamo that kept all this turning, and the Institute breathed a sigh of relief when he left on Thursdays for a two-day flying visit to the New York and Boston offices. As a man of his times, his achievements were considerable; he admired Churchill and his watchword was 'practical idealism'. Later I encountered him again at a meeting in England; he asked me to come back but by then I had settled in another post.

I met a number of the luminaries of the time who were either consulting or lecturing at the Institute. Leucotomy was in vogue, and Freeman and Watts had developed the 'ice-pick' operation mainly as a simple expedient for backwoods hospitals which might be several hundred miles from a medical centre. Freeman, who told me he was basically a pathologist, had a direct style of patient interrogation"Do you get voices in your head, boy? Anybody interfering with your balls?" Watts, his neuro-surgical confrère, later felt the procedure was too inaccurate and gave it up. A much more refined operation, orbital under-cutting, was developed by Scoville, who carried out some operations at Hartford. Bennett demonstrated his technique of muscular relaxation for ECT; it was at first given alone and was not until some time later used in combination with an intravenous anaesthetic. He had a reassuring manner-"You can't move your arm, that's all right. Now you can't lift your head, that's OK. And now you can't breathe, that's fine too." At this point the ECT was administered.

Just before he was appointed to the St Thomas's post, Willam Sargant visited. He delivered rather a spell-binding lecture on his theory of abreaction and the ultra-paradoxical phase, drawing from his experiences of revival meetings in North Carolina involving rhythmic chanting, dance and snake-handling. Professor Adolf Meyer spoke on the psycho-biological school of thought which had flourished in Baltimore since the thirties; I recollect a very telling exposition of how the ego resistances can become "egg-shell thin."

American psychiatry was highly polarised at the time, and you had to declare yourself either for analysis or physical treatment. At one hospital using only a psychoanalytical approach, the therapist told me she would knock on the patient's door, and announce her presence; if there was no response, she would sit outside for the remainder of the hour. To try to persuade the patient more than this she would regard as being too interventionist. The Americans are an ebullient people, and there seemed to be more manic and hyperactive behaviour than one was accustomed to. In those days Before Chlorpromazine, hydrotherapy by wet 
packs and tepid baths was used extensively and not without success.

Visits to Canada, Boston, New York, Baltimore and Washington were rewarding, for the art galleries no less than the psychiatric experience; the Boston Fine Arts Museum in particular was a joy. Montreal presented a fascinating intermingling of cultures; psychiatrically, perhaps it leaned more towards neurological orientations. The Massachusetts state hospital had a research unit possessing a deservedly good reputation for its work, mainly in the biological field. Unfortunately the hospital itself was at that time so sadly depressed in funding that the level of care was painfully low, with a degree of patient degradation which was hurtful to see. This was the era of 'snake pits' in state mental hospitals, which persisted until the Kennedy administration channelled more revenue in their direction Gregory Pincus, the biologist whose work became directed towards the development of the chemical contraceptive pill, was also working in Massachusetts. He was one of the most impressive individuals I have ever met. When I was shown over his laboratory and introduced to his tall and commanding presence, his direct and penetrating gaze seemed to indicate that an instant and complete analysis of my personality inventory had been carried out. This was followed by a smile of great charm which appeared to imply either that he had accepted me, or was too kind to let me know that I was an idiot. Boston had also gone quite far, for that time, into the deployment of psychiatry in the general hospitals, a feature that was later to become "liaison psychiatry'. Harvard had lots of bio-engineers and mathematicians who were prepared to co-operate in the psycho-physiological field, and around this time the foundations of feed-back theory and cybernetics were being laid.

St Elizabeth's Hospital in Washington was vast, over 3,000 beds, and had the additional distinction of harbouring Ezra Pound. Chestnut Lodge sanatorium near Washington specialised in the psychoanalytic treatment of psychotics; a brave effort, but too passive for the taste of most people. The Phipps Clinic in Baltimore had been the centre of excellence of the thirties; still an outstanding clinical school, it was perhaps being outdistanced by others more closely identified with a rigorous scientific approach.

The Veterans' Administration hospitals did a lot of good quality work. Veterans (ex-service people) had a strong lobby, and the level of funding was almost ludicrously adequate in comparison with the state hospitals. VA hospitals were Federal territory, a useful feature for staff who were speeding to work; they had only to drive through the gates to aquire immunity.

But psychiatry on the Eastern seaboard was too pressurised for my liking, so not without regrets for the stimulating medical environment, the hospitable social life and the excellent open-air opportunities we decided to return after the 18 months I had engaged for. I also missed the easy interchange between disciplines in the USA; doctors, biologists, anthropologists, statisticians and engineers, far from retreating within their own bolt-holes, seemed eager to establish points of contact. It is this feature I think which has been fundamental to American technical advancement. On leaving the Institute I was presented with a scroll, the only genuine parchment amongst the records of my qualifications.

Before I left American shores, I had to clear my income tax position. I was told I appeared to owe the internal revenue \$86, but if I returned in a couple of days they might find they had over-estimated. When I did so, they told me that they had now brought it down to $\$ 32$, but if I would leave the problem with them for a few weeks they would be able to remit \$15 to the United Kingdom in my favour as an over-payment ...

A friend in Yorkshire kindly offered me a post until $I$ had acclimatised myself to the newly-formed National Health Service. Within a year I felt I should move on, and applied for two posts almost simultaneously-one at Runwell Hospital with Dr Ström-Olsen, and the other as lecturer at Aberdeen University. Runwell arranged itself very quickly but I heard nothing from Aberdeen. Soon after starting at Runwell I received a belated response from Aberdeen (my old university), went to the interview and got the post. I was somewhat embarrassed at having to explain this odd sequence of events and I suspect that Ström never did quite believe me, thinking I had just used Runwell as a steppingstone to an academic post.

I moved to Aberdeen in 1950, coinciding with a decade of unparalleled development of psychiatry on all fronts. Psychotropics and psychotherapies were successively introduced, discarded and replaced; also the public was suddenly eager to hear about psychiatry, which for a time became not so much oversold as overbought.

With better facilities I now engaged in more technical research. One project was to see whether group learning could be enhanced by pulsing visual information at alpha frequencies rather than at random intervals, but no positive result emerged. Another was a study of blood-pressure readings during a standard interview with normal volunteers. Most subjects encountered some item, or memory, which acted as a stressor and it was interesting that the blood-pressure response to this was greater than the response to a standard physiological stress such as breath-holding. Another unexpected finding was that in such emotional stress responses, the percentage diastolic response was greater than the systolic. Teaching was interesting, and under the energetic leadership of Malcolm Millar we found ourselves practically drawing up a new curriculum, and re-writing all our lectures, every year. It was notable how much better the post-war 'mature students' were; perhaps all medical students should do something practical and entailing responsibility before starting formal study. During the Aberdeen years I wrote an introductory textbook which went into three editions before Livingstone was taken over. I also began to work on a rating scale for depression, but the department all shouted down the idea as too mechanistic, so I dropped it ... one that got away. 
By 1956 I became restless again and took a post as professor at the University of Shiraz in Iran. Going on ahead, I went by the Simplon-Orient Express from Ostend through Paris and Domodossola to Venice. There I met the cultural attache of the London Iranian Embassy, and we then drove via Trieste, Zagreb, Belgrade and Skopje to Salonika in Greece, then along the shores of the Aegean to the Turkish frontier; Istanbul, Ankara and Erzerum took us to the Iranian border. Yugoslavia, Greece and Turkey were not in a good state at that time, and the declining economic gradient from West to East was very noticeable in all of them. The final part of the journey in Iran was through Tabriz to Teheran, and then by air to Isfahan and Shiraz. At that time Iran was intent on modernising itself, and there was a lot of enthusiasm for experts of all kinds prepared to demonstrate Western techniques. We enjoyed the exotic location and the dignified hospitality of the people, the stark landscapes and beautiful gardens - where water could be found for them. The climate was excellent; Shiraz is on a plateau at 6,000 feet, and to our surprise it was a healthy place to live. Our three children were quite well until they were finally repatriated, when they at once succumbed to a succession of infections. The main figure at the University was Dr Ghorban, the Chancellor, whose creation it was. A very kindly, capable and cultured man, I learned later that he held 28 different appointments so he could truly be regarded as a key figure. As no-one was entirely trusted, $\mathrm{Dr}$ Ghorban had to be responsible for everything, from settling policy with the Shah down to signing requisitions for soap. He once confided, "I don't think there can be anything in the world more difficult than starting up a medical school".

I was at first flattered to be given the job of selecting the next intake of medical students, until I learned that everyone else was terrified of it; there were problems such as if one turned down the nephew of a provincial governor, he was liable to close down the faculty. I was held to be ignorant of the niceties of the situation, hence impartial and so an ideal adjudicator. In fact, we worked out a very satisfactory fourpart entrance test. The first screen was ability in Iranian education, the second ability in English; the third hazard was a non-verbal intelligence test and the fourth consisted of the multiple-choice Rorschach test with the intention of revealing personality instability. The group selected in this way did well, with a minimal drop-out rate-and fortunately, no repercussions.

We set up a Department of Mental Health in the Kheoban Zand, the main street, so attracting some notice and not a few customers; we were able to offer psychotherapeutic interviews, narco-analysis sessions, EEG and ECT.
A magazine was also started, Ravan Nema (Mirror of the Mind); to deflect prejudice, we invited a mullah to take a seat on the steering committee. Psychiatry continued to do fairly well after I left, and I was pleased to see some years later that the staffing ran to a Senior Registrar in Psychotherapy - a long way from our humble beginnings.

Sometimes one could feel stifled by the formal manners (taruf), or irritated by the frequent separations from logical thought, but always the next minute charmed by ingenuous kindness. An American anthropologist studying there told me he thought the key to Iranian society was that every man was a king. All business and social affairs were attended by little glasses of the delightfully mild Persian tea made by boiling up the leaves. There was no shadow then of the fundamentalist Islamic revolution, which occurred a whole generation after my experience of Iran.

In my third year there it became clear that the children's education demanded some action; also I felt that professionally speaking, I could stay away too long. The University of Aberdeen had kindly given me leave of absence but I began to wonder whether I should continue indefinitely in academic life. Accordingly I resigned both from Shiraz and from Aberdeen and decided to go back to the NHS on returning to Britain.

Before I left Shiraz, my ever-attendant Iranian assistant told me he would take me on a round of the necessary bureaucratic clearances prior to departure-taxation, military permission, local government and so on. We visited five different offices and my small piece of paper was enthusiastically rubber-stamped by nine different dignitaries. No-one ever asked to see it or even raised the question of its existence...

Soon afterwards I secured an appointment in Bristol, where I worked until my retirement from the Health Service; this period is too recent to be the subject of reminiscence. Things have changed over the years, and change will continue. Clinical syndromes have become less dominant than behavioural anomalies, and perhaps we can less easily stand aside from value judgements. Young people are less neurotic but seemingly more at risk from existentialist despair and from mind-altering drugs. In adult life, leisure is in danger of becoming a full-time occupation as the threat of over-production, dormant for $\mathbf{4 0}$ years, shows its teeth. In old age, it may be that preventive work in Alzheimer's disease will modify the picture with farreaching consequences.

At all events, I do not think that psychiatry stands accused in terms of 'ils n'ont rien oublié et n'ont rien appris'.

\section{Caring for AIDS}

The College is one of the 18 sponsors, including the Department of Health and Social Security, of this national multidisciplinary conference. It will be held at the University of Manchester Institute of Science and Technology (UMIST) from 13-15 November 1987. Registration fees: $£ 115$ before
9 October; $£ 149.50$ after 9 October. The conference is Section 63 (zero rated) approved; study leave should be claimed. Further details: Congresses and Expositions Ltd, 3 The Parsonage, Manchester M3 2HB (telephone 061832 1972). 